\title{
Refractory hepatic hydrothorax: successful treatment with octreotide
}

\author{
M. Barreales, S. Sáenz-López, A. Igarzabal ${ }^{1}$, T. Muñoz-Yagüe, B. Casis, F. Alonso-Navas ${ }^{1}$ and
} J. A. Solís Herruzo

Services of Digestive Diseases and 'Internal Medicine. Hospital 12 de Octubre. Madrid, Spain

\begin{abstract}
We report the case of a patient that developed hepatic hydrothorax as the first complication of liver cirrhosis. Due to the lack of response to diuretics, pleurodesis and TIPS, treatment with octreotide was started with resolution of hydrothorax. To the best of our knowledge, this is the third reported case of refractory hepatic hydrothorax with complete and sustained response to octreotide.
\end{abstract}

Key words: Hepatic hydrothorax. Liver cirrhosis. Ascites. TIPS. Pleurodesis. Octreotide.

Barreales M, Sáenz-López S, Igarzabal A, Muñoz-Yagüe T, Casis B, Alonso- Navas F, Solís-Herruzo JA. Refractory hepatic hydrothorax: successful treatment with octreotide. Rev Esp Enferm Dig 2005; 97: 830-835.

\section{INTRODUCTION}

Hepatic hydrothorax is an infrequent complication of liver cirrhosis $(5-10 \%)(1,2)$. It is defined as pleural effusion greater than $500 \mathrm{ml}$ in patients with liver cirrhosis and portal hypertension without cardiopulmonary disease. There are many pathophysiologic theories that try to explain the mechanism of hepatic hydrothorax. Currently, the most accepted mechanism, involves the passage of ascitic fluid from the peritoneal cavity into the pleural space through diaphragmatic defects (2-4). Pleural effusión meets transudative criteria and is located in

\section{Recibido: 05-05-05.}

Aceptado: 10-05-05.

Correspondencia: M. Barreales. Servicio de Medicina de Aparato Digestivo. Hospital 12 de Octubre. Ctra. de Andalucía, s/n. Madrid the right hemithorax in $85 \%$ of cases $(2,3)$. It is usually associated with ascites but there are cases of isolated hydrothorax (5-7). Initial treatment is similar to that of hydropic decompensation and it consists of fluid and sodium restriction and diuretics. Patients with hydrothorax refractory to pharmacological treatment can be managed with pleurodesis or transjugular intrahepatic portosystemic shunt (TIPS) (8-13), although liver transplantation is the definitive treatment (14). Over the last few years, two cases of successful treatment of hepatic hydrothorax with octreotide have been reported. This led us to treat our patient with this drug.

\section{CASE REPORT}

A 66-year-old woman, with a past medical history of cigarette smoking and active alcohol consumption of 70 grams per day. Premature menopause treated with estrogens for more than 20 years. She was admitted to another hospital the previous month with right hydrothorax. She was diagnosed with hepatic hydrothorax with a liver biopsy that revealed early micromacronodular cirrhosis, with moderate activity and focal steatosis. Viral, metabolic and autoimmune test were negative for the aetiology of liver disease. Cardiopulmonary disease, as well as infectious disease, tuberculosis and pleural or lung cancer were excluded as the cause of the pleural effusion. Due to the absence of response to fluid and sodium restriction and diuretics she was submitted to thoracentesis and chest tube insertion to alleviate symptoms.

She was admitted to our hospital one month later with recurrent right hydrothorax. Physical examination showed decreased breath sounds over the right inferior hemithorax. Blood cell count revealed leukocytosis of $20.500 / \mu \mathrm{L}$ with $77 \%$ of neutrophils. Other laboratory values were as follows: creatinine level $1.9 \mathrm{mg} / \mathrm{dl}$, sodium $129 \mathrm{mEq} /$ liter, potasium $5.4 \mathrm{mEq} / \mathrm{liter}$, total protein 5.68 
$\mathrm{g} / \mathrm{dl}$, albumin $2.44 \mathrm{~g} / \mathrm{dl}$, glutamic oxalacetic transaminase $107 \mathrm{UI} / \mathrm{Liter}$, glutamate pyruvate transaminase $52 \mathrm{UI} / \mathrm{L}$, lactate dehydrogenase $157 \mathrm{UI} / \mathrm{L}$, total bilirubin 1.81 $\mathrm{mg} / \mathrm{dl}$, gamma glutamyl transferase $370 \mathrm{UI} / \mathrm{L}$, alkaline phosphatase $278 \mathrm{UI} / \mathrm{L}$, prothrombin activity $69 \%$, cephaline time 30 seconds, fibrinogen $283 \mathrm{mg} / \mathrm{dl}$ and alpha fetoprotein $6 \mathrm{ng} / \mathrm{ml}$. Serologies for HBV, HCV, EpsteinBarr virus and syphilis were negative. On admission, pleural fluid analysis met exudative criteria (total protein $3.34 \mathrm{~g} / \mathrm{dl}$; LDH $427 \mathrm{UI} / \mathrm{L} ; \mathrm{pH} 7.073$, glucose $62 \mathrm{mg} / \mathrm{dl}$; albumin $1.82 \mathrm{mg} / \mathrm{Dl}$, leukocytes $648 \mathrm{cel} / \mathrm{mm}^{3}$ with $50 \%$ of neutrophils) with positive culture for coagulase-positive Staphylococcus aureus sensitive to oxacilin. Tuberculosis was excluded by the determination of alcoholacid resistant bacilli and gamma-interferon in pleural fluid and negative mantoux. Moreover, malignancy was ruled out by cytologic examination of pleural fluid and pleural biopsy. Doppler ultrasound revealed signs of chronic liver disease without morphologic nor hemodynamic signs of portal hypertension, mild ascites and right pleural effusion. On the basis of absence of response to fluid and sodium restriction and diuretics, a chest tube was placed to relieve symptoms, with drainage of 2000$2500 \mathrm{cc}$ of fluid per day. Pleural effusion was complicated by acute prerenal failure due to excessive fluid loss and hypoproteinemia with hypoalbuminemia. In an attempt to control pleural fluid formation, a minithoracotomy with talc pleurodesis was performed without success. After pleurodesis failure, and with hemodynamic evidence of mild portal hypertension (hepatic venous pressure gradient: $13 \mathrm{mmHg}$ ) which suggested liver disease as the cause of hydrothorax, TIPS placement was considered. There was a transient (2-3 days) decrease in chest drainage volume. TIPS dysfunction was ruled out by doppler ultrasound. Due to the severity of the disease and the absence of other therapeutical options, treatment with intravenous octreotide was started fifteen days later, at a dose of $25 \mu \mathrm{g} / \mathrm{h}$ on the first day, $50 \mu \mathrm{g} / \mathrm{h}$ on the second day and then $100 \mu \mathrm{g} / \mathrm{h}$ for five more days. The patient had a good response to treatment with progressive decrease in chest tube drainage, allowing chest tube removal without recurrence of pleural effusion. Before discharge, a single dose of $10 \mathrm{mg}$ subcutaneous octreotide was administered. No recurrence of hydrothorax or ascites has occurred within six months of discharge with a $25 \mathrm{mg}$ dose of aldactone daily.

\section{DISCUSSION}

Hepatic hydrothorax is a rare complication of cirrhosis that is defined as accumulation of ascitic fluid in the pleural space $(>500 \mathrm{ml})$, in a patient with liver cirrhosis and portal hypertension, in the absence of cardiopulmonary disease. The estimated prevalence of this complication in patients with liver cirrhosis is $5-10 \%(1,2,14)$. Its pathophysiology is unclear and it involves movement of ascitic fluid from the peritoneal cavity to the pleural space through micro- or macroscopic diaphragmatic defects (15-18). Pleural effusion is usually a transudate. In our case, the presence of pleural exudate with positive culture for coagulase-positive Staphylococcus aureus was interpreted as empyema secondary to previous procedures. Findings allowed the exclusion of tumoral and infectious diseases and the presence of signs of portal hypertension led to the diagnosis of cirrhosis as the cause of hydrothorax.

The management of this complication is usually difficult, with few therapeutical options. The aim of the treatment is to decrease ascites formation and/or portal hypertension. The only definitive treatment is liver transplantation $(19,20)$, and it must be always considered in these patients. Initial treatment is similar to that of ascites and consists of fluid and sodium restriction and diuretics $(16,20)$. Refractory hepatic hydrothorax is defined as pleural effusion that persists despite adequate treatment with the highest tolerable dose of diuretics. These are the most severely ill and difficult patients. Management is dependent on respiratory symptoms caused by hydrothorax (16) and consist of several therapeutic approaches: repeated thoracenteses, chest tube insertion, pleurodesis and TIPS.

Patients with severe dysnea often require chest tube placement, which is also used to treat iatrogenic or spontaneous infection of pleural effusion. This procedure has many complications such as excessive protein, fluid and electrolyte depletion. Chest tube removal is often impossible due to high volume drainage. This has led many authors to contraindicate chest tube placement in these patients (16).

There are some reported cases of successful treatment with pleurodesis. Talc is administered during thoracoscopy, performed to repair diaphragmatic defects if detected. However, this treatment has a high morbimortality rate as it is an invasive technique and it is usually performed in severely debilitated patients $(16,21)$. We considered this option for our patient due to the absence of response to previous treatments and with the objective of pleurodesis and detection of diaphragmatic defects, as well as to perform a close examination of the thoracic cavity, taking biopsy samples to definitely exclude malignancy. The procedure was unsuccessful maintaining high chest tube drainage that did not allow chest tube removal.

According to literature, TIPS is the most effective treatment for refractory hepatic hydrothorax and it is considered one of the indications for this technique $(9,15,16)$. Apart from reducing hepatic venous pressure gradient, it improves renal function (20). It has also been reported to facilitate chest tube removal $(15,18)$. Although it is a safe, little-invasive and efficient procedure, it has two major inconveniences: frequent obstruction of the prosthesis and development of hepatic encephalopathy (9). To prevent adverse outcomes after TIPS placement, patients should be carefully selected, avoiding 
those with hepatic encephalopathy or with Child C cirrhosis (16). After pleurodesis failure and once excluded etiologies for hydrothorax other than liver disease, our patient underwent a hemodynamic study. Based on hemodynamic evidence of mild portal hypertension, TIPS was performed. There was an initial response after the procedure, with a decrease in chest drainage volume, that did not allow chest tube removal. This response was transient as drainage volume subsequently increased despite normal function of the prosthesis, as assesses by doppler ultrasound. Besides, she developed hepatic encephalopathy that responded to conventional treatment. There are two reported cases of treatment of refractory hepatic hydrothorax with octreotide in patients without other invasive options because of poor condition. Treatment with octreotide was justified as it has the same effect as TIPS in reducing portosystemic pressure gradient. This drug has few and minor side effects $(15,20)$. Based on good response to octreotide treatment in these cases we considered this treatment for our patient. We administered the same doses as those reported in the literature: $25 \mu \mathrm{g} / \mathrm{h}$ on the first day, $50 \mu \mathrm{g} / \mathrm{h}$ on the second day and then $100 \mu \mathrm{g} / \mathrm{h}$ for five more days. In the reported cases, the effect was dose dependent since higher doses led to greater reduction of drainage volume. Our patient had progressive improvement, allowing chest tube removal after five days of treatment (Fig. 1). We decided to continue treatment for several days by subcutaneous administration before discharge. Hydrothorax has not recurred within six months of discharge.

To the best of our knowledge, this is the third reported case of refractory hepatic hydrothorax with response to octreotide. Contrary to the two previous case reports $(15,20)$, our patient had failed to all available treatment options, including pleurodesis and TIPS. It is possible that TIPS and octreotide had a summatory effect on the decrease of portal hypertension. Based on this favorable response to octreotide, we think that splanchnic vasoconstrictors should be considered in the treatment of serious complications such as refractory hepatic hydrothorax and ascites.

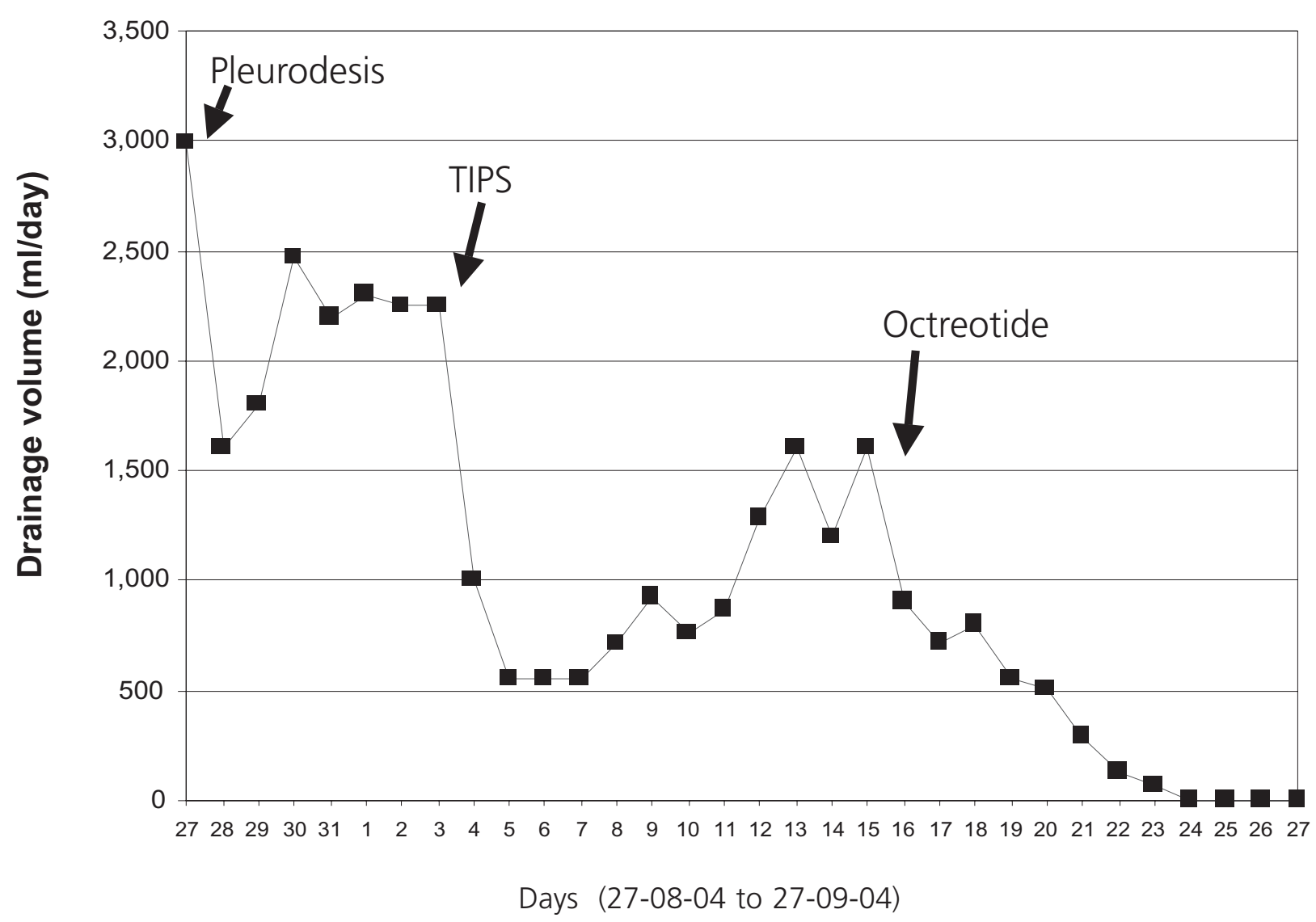

Fig. 1.- Effect of different treatments on chest tube drainage volume. On 27-08-2004 talc pleurodesis was performed with minimal effect on daily drainage volume, as shown in the figure. On 2-09-2004 TIPS placement was performed with significant initial response but with subsequent increase in chest tube drainage volume. Finally, on 17-09-2004 octreotide treatment was started, allowing chest tube removal in the absence of drainage. Evolución del drenaje endotorácico tras los distintos tratamientos. En el día 27-08-2004 se realizó una pleurodesis con talco, que, como puede verse en el gráfico, apenas tuvo efecto sobre la cantidad de líquido drenado diario. El día 2-09-2004 se colocó la DPPI con una Ilamativa mejoría inicial pero con posterior empeoramiento del drenaje. Finalmente, el día 17-09-2004 se inició el tratamiento con octreótido logrando retirar el tubo de tórax ante la ausencia de drenaje. 


\section{REFERENCES}

1. Morrow CS, Cantor M, Armen RN. Hepatic hydrothorax. Ann Intern Med 1958; 49: 193-203.

2. Lazardis KN, Frank JW, Krowka MJ, Kamath PS. Hepatic hydrothorax pathogenesis, diagnosis and management. Am J Med 1999; 107: 262-7.

3. Alberts WM, Salem AJ, Solomon DA, Boyce G. Hepatic hydrothorax. Cause and management. Arch Intern Med 1991; 151: 2383-8.

4. Lieberman FL, Hidemura R, Peters RL, Reynolds TB. Pathogenesis and treatment of hydrothorax complicating cirrhosis with ascites. Ann Intern Med 1966; 64: 342-51.

5. Golpe R, García L, García MM, Sánchez E, Jiménez A. Hidrotórax hepático sin ascitis: presentación de un caso y revisión de la literatura. An Med Interna 1998; 15: 541-3.

6. Strauss RM, Martin LG, Kaufman SL, Boyer TD. Transyugular intrahepatic portal systemic shunt for the management of symptomatic cirrhotic hydrothorax. Am J Gastroenterol 1994; 89: 1520-2.

7. Gordon FD, Anastopoulos HT, Crenshaw W, Gilchrist B, McEniff N, Falchuk KR, et al. The successful treatment of symptomatic refractory hepatic hydrothorax with transjugular intrahepatic portosystemic shunt. Hepatology 1997: 25: 1366-9.

8. Chalasani N, Martin LG, Strauss RM, Boyer TD. Transjugular intrahepatic portosystemic shunt (TIPS) for refractory hepatic hydrothorax (HHRT)- Good for the lung, not so good for the liver. Hepatology 1997; 26: A630.

9. Núñez O, García A, Rincón D, Alonso S, Echenagusía A, Bañares R. Derivación portosistémica percutánea intrahepática como tratamiento del hidrotórax hepático refractario. Gastroenterol Hepatol 2002; 25 (3): 143-7.

10. Milanez de Campos JR, Filho LO, de Campos Werebe E, Sette H Jr, Fernandez A, Filomeno LT, et al. Thoracoscopy and talc poudrage in the management of hepatic hydrothorax. Chest 2000; 118 (1): 2-4

11. Kakizaki S, Yoshinaga T, Higuchi T, Takayama H, Takagi H, Nagamine T, et al. Hepatic hydrothorax in the absence of ascites. Liver 1998; 18: 216-20.

12. Kirsch CM, Chui DW, Yenokida GG, Jensen WA, Bascom PB. Case report: hepatic hidrothorax without ascites. Am J Med Sci 1991; 302: 103-6.

13. Xiol X, Cortes R, Castellote J, Sese E, Guardiola J, Bofargues JM, et al. Utility and complications of thoracocentesis in cirrhotic patients. Hepatology 1997; 26: A632.

14. Kinasewitz GT, Keddissi JI. Hepatic hydrothorax. Curr Opin Pulm Med 2003; 9: 261-5.

15. Pfammatter R, Quattropani C, Reichen J, Göke B, Wagner AC. Treatment of hepatic hydrothorax and reducion of chest tube output with octreotide. Eur J Gastroenterol Hepatol 2001; 13: 977 80 .

16. Cárdenas A, Kelleher T, Chopra S. Review article: hepatic hydrothorax. Aliment Pharmacol Ther 2004; 20: 271-9.

17. Ajmi S, Hassine H, Guezguez M, Elajmi S, Mrad Dali K, Karmani M et al. Isotopic exploration of hepatic hydrothorax: ten cases. Gastroenterol Clin Biol 2004; 28: 462-6.

18. Conklin LD, Estrera AL, Weiner MA, Reardon PR, Reardon MJ. Transjugular intrahepatic portosystemic shunt for recurrent hepatic hydrothorax. Ann Thorac Surg 2000; 69: 609-11.

19. García N, Mihas AA. Hepatic hydrothorax: pathophysiology, diagnosis, and management. J Clin Gastroenterol 2004; 38: 52-8.

20. Dumortier J, Lepretre J, Scalone O, Boillot O, Scoazec JY, Delafasse B, et al. Successful treatment of hepatic hydrothorax with octreotide. Eur J Gastroenterol hepatol 2000; 12: 817-20.

21. Ferrante D, Arguedas MR, Cerfolio RJ, Collins BG, Van Leewen DJ. Video-assited thoracoscopic surgery with talc pleurodesis in the management of symptomatic hepatic hydrothorax. Am J Gastroenterol 2002; 97: 3172-5. 